SPECIAL REPORT 17

COALS OF THE ANCHORAGE QUADRANGLE, ALASKA

By

C.N. Conwell, D.M. Triplehorn, and V.M. Ferrell

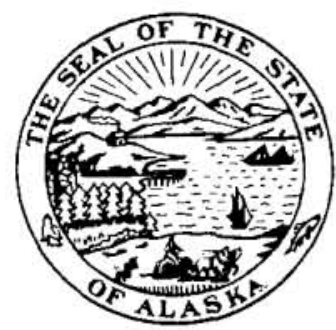

COLlege, ALASKa

1982 
STATE OF ALASKA

Jay S. Hammond, Governor

John W. Katz, Commissioner, Dept. of Natural Resources

Geoffrey Haynes, Deputy Commissioner

Ross G. Schaff, State Geologist

Cover photo: Southwest view, Premier group coal seam, Chickaloon Formation, western Wishbone Hill area.

For sale by Alaska Division of Geological and Geophysical Surveys, P.O. Box 80007, College, 99708; 323 E. 4th, Anchorage, 99501; P.O. Box 2438, Ketchikan, 99901; and 230 S. Franklin, Juneau, 99811. Cost: \$3. 


\section{TABLE OF CONTENTS}

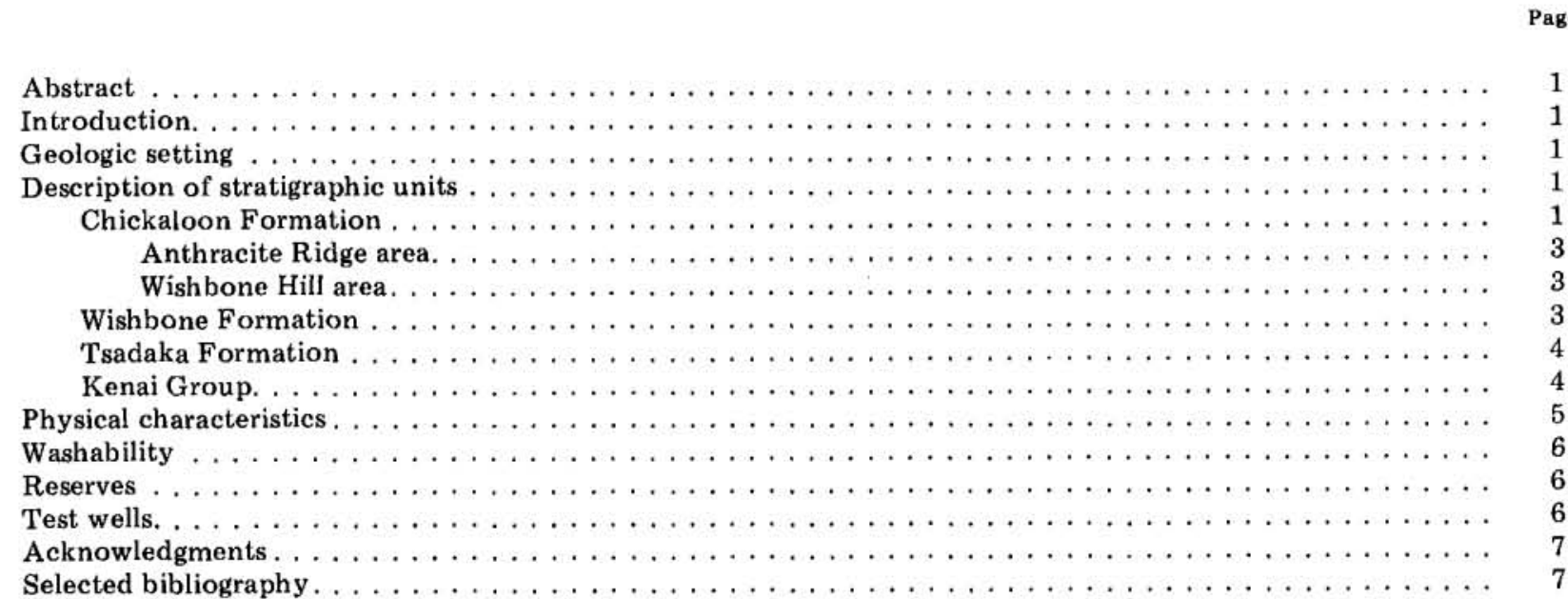

\section{ILLUSTRATION}

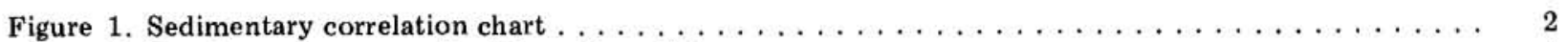

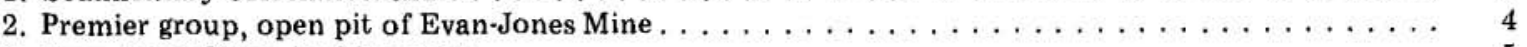

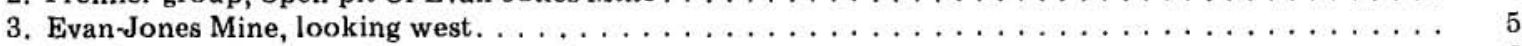

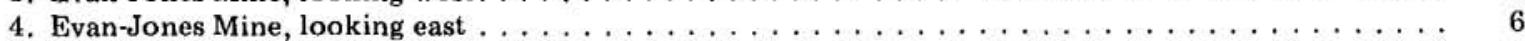

\section{PLATES}

Plate 1. Geologic map of the Susitna, upper Cook Inlet, and Matanuska Valley coal provinces.

2. Correlation of stratigraphic sections interpreted from well-log data in the Susitna and upper Cook Inlet basins.

3. Geologic cross sections, Matanuska Valley.

4. Generalized stratigraphic sections, Matanuska Valley. 


\title{
COALS OF THE ANCHORAGE QUADRANGLE, ALASKA
}

\author{
By C.N. Conwell ${ }^{1}$, D.M. Triplehorn ${ }^{2}$, and V.M. Ferrell ${ }^{1}$
}

\begin{abstract}
Three coal-bearing provinces have been defined in the Anchorage Quadrangle: a) the eastern area or Matanuska Valley province, where coal grades range from bituminous to anthracite (the principal resource is a bituminous coal in the Wishbone Hill area); b) the Susitna province, where the coal is subbituminous and occurs in the middle and upper Kenai Group (a small reserve near Houston has coals up to $10 \mathrm{ft}$ thick in a zone less than $1,000 \mathrm{ft}$ below the surface); and c) the Cook Inlet province, where coals of the Hemlock and Tyonek Formation equivalents may overlap with those of the Matanuska Valley province. The Premier group coals in the Matanuska Valley province have been radiometrically dated at $55 \mathrm{~m} . \mathrm{y}$.
\end{abstract}

\section{INTRODUCTION}

Coal mining near Anchorage, Alaska began in 1916 and continued for a half century, ending when natural gas from the nearby Swanson River field was brought on-line in 1967. However, interest in the abundant coal reserves in this area has revived, chiefly because of the continuing rise in petroleum costs, both here and abroad, and also as a result of national energy policies.

\section{GEOLOGIC SETTING}

Coal-bearing Tertiary rocks at the northeast end of Cook Inlet occur in three sedimentary provinces (pl. 1). North of the Castle Mountain fault and west of the Talkeetna Mountains is the Susitna province, where the Tertiary section is relatively thin and nearly horizontal, presumably because of the lack of deposition and erosion on the uplifted block north of the fault. Southeast of the Susitna basin and across the Castle Mountain fault is the northeastern part of the Cook Inlet province; this area, bounded by the Castle Mountain and Border Ranges faults, contains thick, flat-lying or only gently folded mid-Tertiary and younger sediments. Immediately to the east is the Matanuska Valley province, a relatively narrow trough of thinner, early Tertiary sediments compressed between the Chugach and Talkeetna Mountain ranges.

\footnotetext{
${ }^{1}$ DGGS, College, Alaska 99708.

${ }^{2}$ Geology-Geophysics Program, University of Alaska, Fairbanks, Alaska 99701 .
}

The relationship between the Cook Inlet province and the Matanuska Valley province is not clear; perhaps the latter should be considered an eastern arm of the larger Cook Inlet basin. In essence, the Matanuska Valley was the site of a Paleocene (Chickaloon Formation) depocenter northeast of the Eocene to Pliocene (Kenai Group) Cook Inlet basin. Some overlap of the two provinces is shown on plate 1 because the Chickaloon Formation underlies Kenai Group sediments or their equivalents near the northeast end of Knik Arm.

Coals in the Anchorage Quadrangle occur primarily in the lower part of the Kenai Group and the upper part of the Chickaloon Formation. Individual coal beds or coal groups do not correlate between the widely spaced boreholes for the Kenai Group. McGee and O'Connor (1975) concluded that, "The coal beds in the Cook Inlet are lenticular and even the thickest beds are difficult to correlate beyond a lateral distance of $7,000 \mathrm{ft}$."

Rock units and correlations (fig. 1, pl. 1) are taken from Magoon and others (1976), and stratigraphic sections (pls. 1, 2) are interpreted from well logs in the late Tertiary Kenai Group. The abrupt thinning of 'Tertiary rocks across the Castle Mountain fault is evident on cross-section A-A'. Section B-B' illustrates the eastward thinning of the Kenai Group toward the edge of the Cook Inlet basin (pl. 2). Plate 3 is a compilation of geologic cross sections from the Matanuska Valley province (Waring, 1936; Barnes and Payne, 1956; Barnes, 1962a). Rock sequences of the early Tertiary Chickaloon Formation from two outcrop areas, Wishbone Hill and Anthracite Ridge, are shown on plate 4 (Barnes and Payne, 1956).

\section{DESCRIPTION OF STRATIGRAPHIC UNITS}

\section{CHICKALOON FORMATION}

Most coal production has come from the thick sedimentary-rock section around Wishbone Hill. Farther east, near the limit of Chickaloon Formation outcrops, the exposed section is thinner and is associated with lava flows and sills that have increased the rank of the coals on Anthracite Ridge. 
SPECIAL REPORT 17

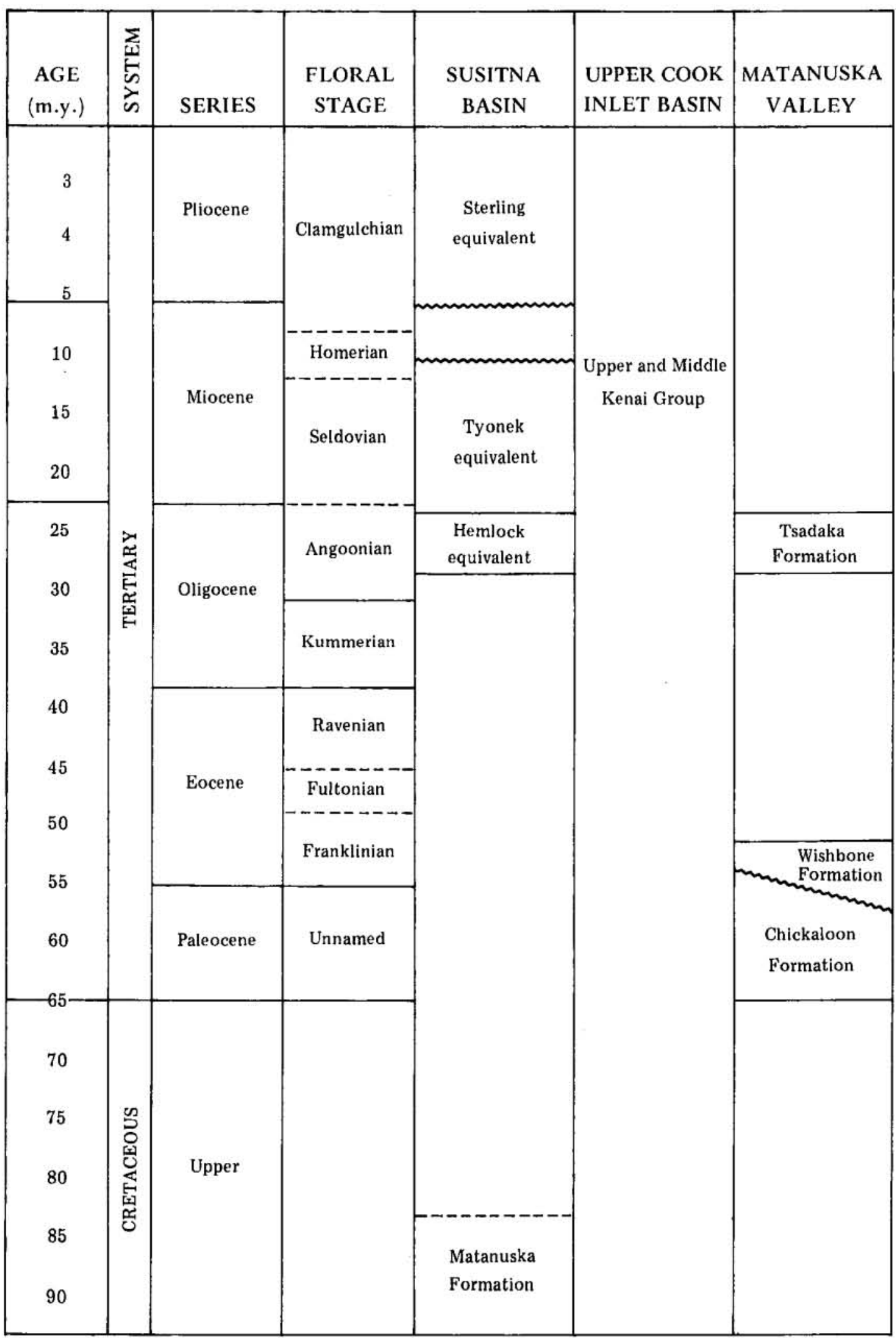

Figure 1. Sedimentary correlation chart. 


\section{ANTHRACITE RIDGE AREA}

At least 2,000 ft of the Chickaloon Formation is exposed along Anthracite Ridge. Outcrop consists of interbedded sandstone and shale and includes three coal units in the lower 1,500 to $1,600 \mathrm{ft}$. Shales are dark gray to black, carbonaceous, and weather with a conchoidal fracture. Sandstones are gray to yellowish, feldspathic, and fairly well consolidated; a basal sandstone is greenish gray, chloritic, and thick bedded. Scattered throughout the formation are beds of conglomerate consisting of well-rounded quartz and chert pebbles. A 30 - to 50 -ft-thick white band that crops out along the central part of Anthracite Ridge consists of well-rounded quartz pebbles that grade westward into a coarse sandstone underlain by a white hardened shale.

The three coal units consist of beds 1 to $10 \mathrm{ft}$ thick that grade laterally into claystone or shale and generally thin westward (pl. 4). The upper and middle coal zones crop out in the basin of Muddy Creek and all three units are exposed on lower Purinton Creek, where many small intrusive bodies often cut across coal beds and sometimes alter their rank and mineability. Coals in this part of the section range from bituminous to anthracitic.

\section{WISHBONE HILL AREA}

The Chickaloon Formation in the Wishbone Hill area consists of 3,000 to $5,000 \mathrm{ft}$ of claystone, siltstone, and sandstone with thin beds and lenses of fine-grained conglomerate and numerous coal beds. The lower part of the formation is mainly dark-purplish-gray claystone with minor siltstone; sandstone beds grade into finegrained conglomerate, and only thin coal streaks and lenses are present. The upper $1,400 \mathrm{ft}$ contain light-gray to buff, poorly stratified claystone and sandstone beds with scattered conglomerate lenses. The sandstone is generally poorly indurated but in places is cemented with iron and calcium carbonate and forms resistant ridges. Many coal beds occur in the upper part of the formation, but often grade into clays and shales or are faulted out. Five coal-bearing intervals (pl. 4) are recognized (D-D', pls. 1, 3). In ascending order they are:

1. Burning-bed coal group. This $15-$ to 125 - $\mathrm{ft}$ thick group appears to pinch out in the center of Wishbone Hill; it is thickest on the northeast and southwest ends. Two to eight individual coal beds (none greater than $3 \mathrm{ft}$ thick) are separated by partings and thin beds of bony coal and clay. stone.

2. Eska coal group. About 200 to $300 \mathrm{ft}$ above the Burning-bed group is the Eska coal group, which is composed of the Martin, Shaw, and Eska beds, in ascending order. These coal beds vary considerably in thickness across Wishbone
Hill. The Martin bed consists of one to three benches, each with 1 to $3.5 \mathrm{ft}$ of clean coal. The Shaw bed occurs mainly as two benches, each 2 to $3.5 \mathrm{ft}$ thick, separated by coaly claystone and claystone; in the central Wishbone Hill area, the Shaw bed appears to pinch out and grade into coaly claystone. The Eska bed consists of layers of 0.8 - to 5.8-ft-thick clean coal with bony coal and claystone partings and interbeds.

3. Midway coal bed. In the eastern Wishbone Hill area, the Midway coal bed is generally composed of two ooal benches, each from 1 to $2.5 \mathrm{ft}$ thick, separated by up to $3 \mathrm{ft}$ of coaly claystone or claystone. To the west, the bed increases to a 7.5- to 12-ft thickness and consists of bony coal, coaly claystone, claystone, and layers of ironstone.

4. Premier coal group. This group occurs $75 \mathrm{ft}$ above the Midway coal bed and includes a number of closely spaced beds in the western Wishbone Hill district. (Figure 2 shows the com. plex folding and near-vertical beds in this area; the cover photo, taken in the eastern part of the Wishbone Hill area, shows the Premier group in the open pit of the Evan-Jones Mine.) About one-third of this 90 - to 100 -ft-thick group is coal. An increase in siltstone and silty-claystone content results in rapid eastward thickening---to $260 \mathrm{ft}$. Several radiometric ages have been deter. mined on minerals separated from volcanic ash partings in coals of the Premier group (Triple. horn, D.M., and Turner, D.L., University of Alaska, in preparation). The average of these ages is about 55 m.y., which indicates a late Paleocene or early Eocene age for the Premier group here.

5. Jonesville coal group. The Evan-Jones Mine (figs. 3,4 ) is in this uppermost coal group, which is about $120 \mathrm{ft}$ thick and consists of four coal beds, each 2 to $5 \mathrm{ft}$ thick. To the west, at Moose Creek, the group contains much bony coal and is of lower quality.

\section{WISHBONE FORMATION}

The Wishbone Formation, which unconformably overlies the Chickaloon Formation, coarsens upward from sandstones and silty claystones at the base to massively bedded conglomerate and sandstone. The pebbles, which are well rounded and poorly sorted, consist primarily of volcanic and metamorphic clasts with some chert, vein quartz, and jasper. Thick crossbedded sandstone units are more common in the upper part. The formation is well indurated and forms prominent scarps at Wishbone Hill and Castle Mountain, where it is about 2,000 and $3,000 \mathrm{ft}$ thick, respectively. 


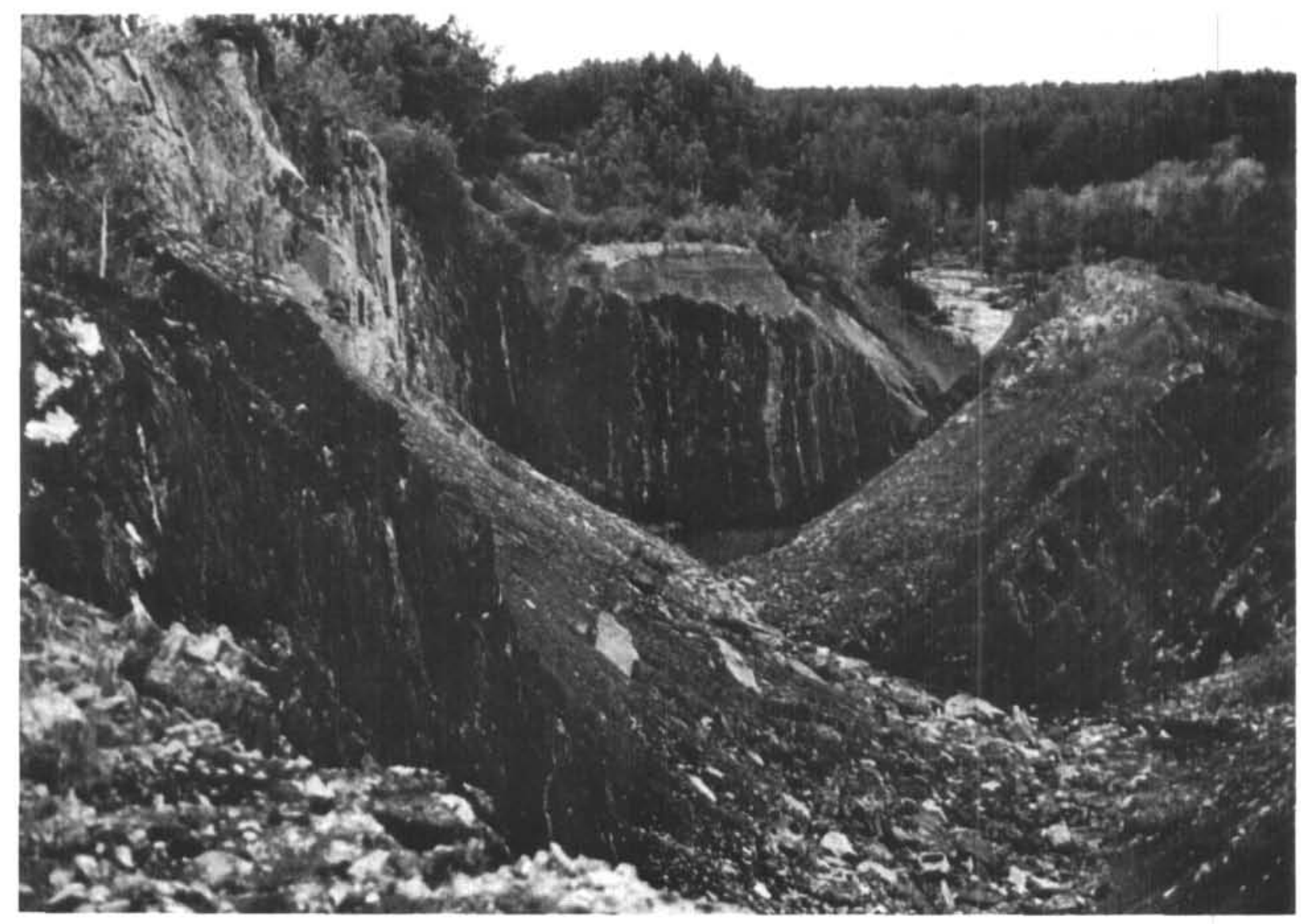

Figure 2. Premier group, open pit of Evan-Jones Mine.

\section{TSADAKA FORMATION}

The Tsadaka Formation is a poorly indurated, coarse-grained conglomerate that overlies the Wishbone Formation with angular unconformity. Pebbles are dominantly felsic plutonic rock types, contrasting sharply with the predominantly volcanic clasts in the underlying Wishbone Formation. Cobble- to bouldersize clasts of diorite and granite imbedded in a matrix of granitic debris crop out as a 45 - to 100 -ft-thick basal conglomerate. The upper part of the formation consists of interbedded silty sandstone, siltstone, pebble sandstone, and fine- to coarse-grained conglomerate.

\section{KENAI GROUP}

The Kenai Group has been divided into five formations by Calderwood and Fackler (1972). These units have been defined in oil-well logs in the Cook Inlet subsurface, where they are very thick and lithologically distinct. However, the study area is near the basin margin, where unconformities, changes in thickness and lithology, and proximity to major faults make correlation difficult.
Only three of the five Kenai Group formations are present in the northeast part of the Cook Inlet basin (pl. 2).

1. Hemlock Conglomerate. This lowermost unit of the Kenai Group is characterized by whitequartz and black-chert clasts in the Cook Inlet basin. On the basis of lithology and stratigraphic position, this unit is correlated with the Tsadaka Formation. As shown on plate 2, Hartman and others (1972) recognized Hemlock-equivalent rocks at the eastern end of Cook Inlet, where they are in part coal bearing.

2. Tyonek Formation. In the Cook Inlet basin, this unit is characterized by massively bedded sandstones and thick coal beds, which distinguish it from the thinner bedded sandstone, claystone, and lignitic coals of the overlying Beluga Formation (which is not present in the northeastern Cook Inlet basin). Claystone interbeds are commonly bentonitic. Toward the basin margins, the formation grades into sandy siltstone, claystone, and coal. 


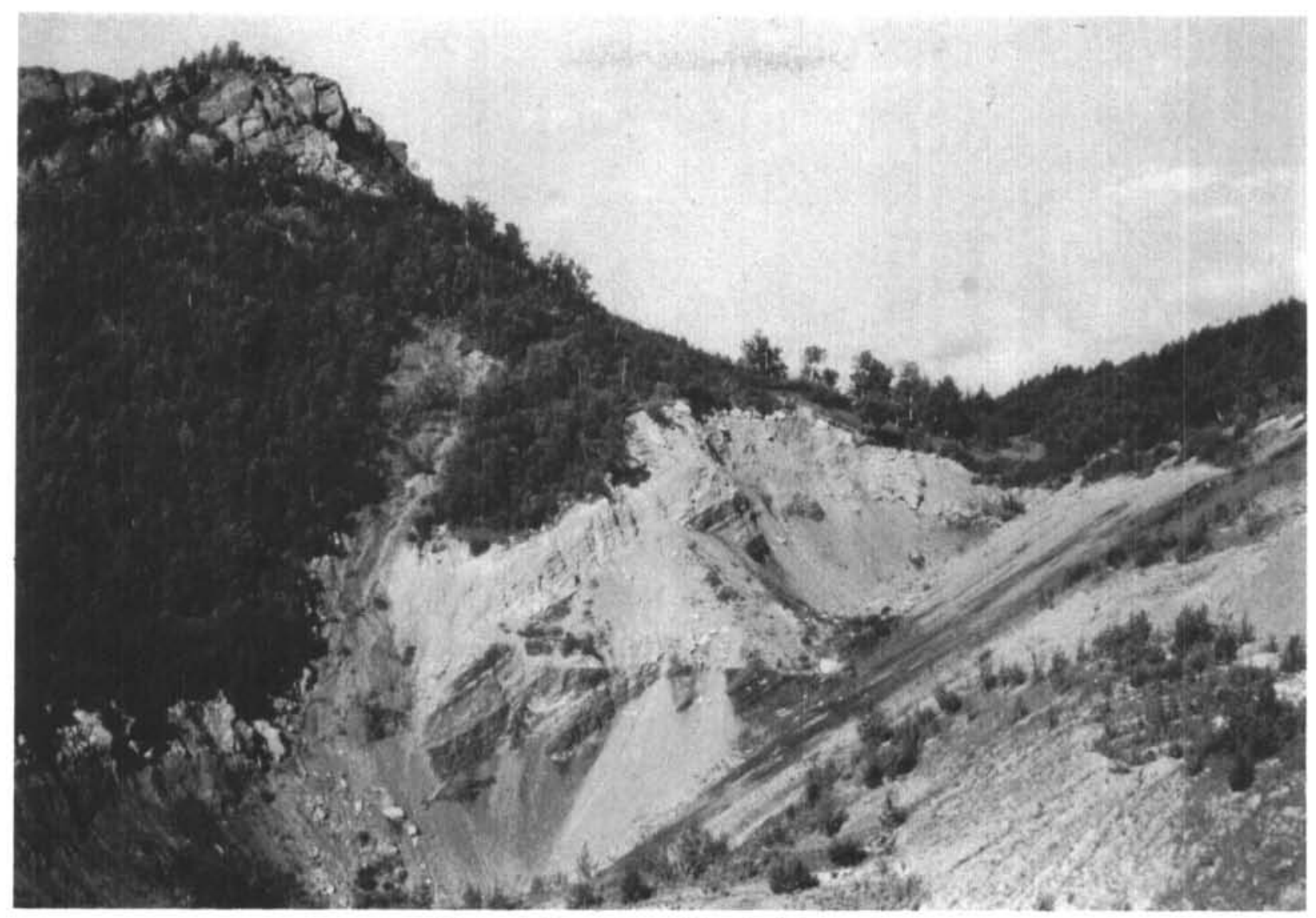

Figure 3. Evan-Jones Mine, looking west.

3. Sterling Formation. Primarily a sandy unit with minor claystones and a few lignitic coals (deeper part of Cook Inlet basin), the Sterling Formation is conglomeratic near the basin margins. In the study area it is recognized only as 'Sterling equivalent,' or undifferentiated upper Kenai Group. The formation is generally unconsolidated and difficult to distinguish from Quaternary sediments.

\section{PHYSICAL CHARACTERISTICS}

Coals in the Anchorage Quadrangle range from bituminous and anthracitic in the Chickaloon Formation of the Matanuska Valley field to subbituminous and lignitic in the Kenai Formation in the Cook Inlet. Accordingly, the characteristics of the coals vary.

The proximate analyses of raw coals from Wishbone Hill vary as follows:

Moisture ...... 3 to 7 percent

Volatile matter....33 to 41 percent

Fixed carbon .....37 to 47 percent

Ash. . . . . . . . 5 to 24 percent

Heating value . 10,400 to $12,500 \mathrm{Btu}$
The proximate analyses of coal from Anthracite Ridge, in the eastern part of the Matanuska basin, are:

Moisture ...... 2 to 7 percent

Volatile matter. . . 8 to 32 percent

Fixed carbon ....4 to 81 percent

Ash. ........ 4 to 22 percent

Heating value .. 11,510 to $14,210 \mathrm{Btu}$

Except for the Castle Mountain 1 seam, which has a free-swelling index of 8 (Rao, 1975), none of the coals are of coking quality. However, there are no known deleterious trace elements.

Coals in the Little Susitna district (Houston area) are on the borderline between high-volatile bituminous $\mathrm{C}$ and subbituminous $\mathrm{A}$. The variation in proximate analyses is:

Moisture . . . . . 14.1 to 20.3 percent

Volatile matter . . . .31.3 to 32.5 percent

Fixed carbon .....34.1 to 38.9 percent

Ash. . . . . . . 9.2 to 20.5 percent

Heating value ... 8,460 to $9,210 \mathrm{Btu}$

Our study of coals in the subsurface in the western part of the quadrangle is based on an interpretation of oil-well logs (pl. 2). The reconstruction does not reflect the abundance of thinner coals (less than $2 \mathrm{ft}$ thick) and 


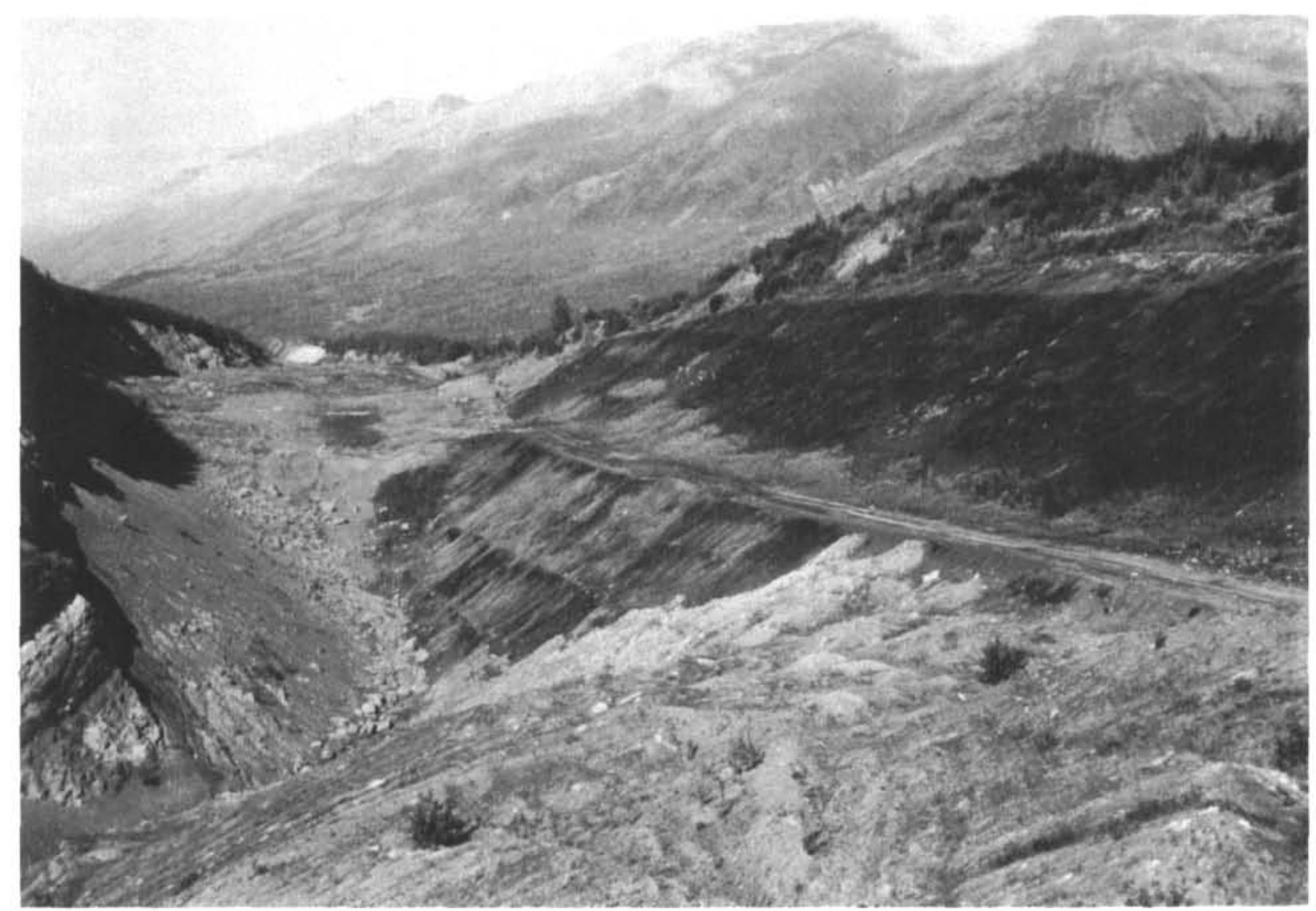

Figure 4. Evan-Jones Mine, looking east.

the existence of 'dirty' partings and interbeds within the thicker coals; these are probably subbituminous.

\section{WASHABILITY}

During production years, most coals from the Matanuska Valley and Houston areas were washed; 65,000 tons of Houston coal mined between 1949 and 1952 was washed in a plant with a Forester jig. Geer and Yancey (1946) describe the mechanical cleaning of Matanuska Valley coals; Geer and Fennessey (1962) completed additional washability studies of several beds in the Wishbone Hill area. A review of the sink-float analyses of a number of individual beds reveals that the separation of coal from ash ranges from easy to extremely difficult (Conwell, 1975). Maximum use of the resource might be a multiseam cleaning plant that produces three separates: a) $a+10$-percent ash product, b) a 10- to 26-percent ash product, and 3) a reject.

\section{RESER VES}

The only coal reserves in the Anchorage Quadrangle are in the Matanuska Valley. Barnes and Payne (1956) reported a total reserve of 112.5 million tons of bituminous coal for the Wishbone Hill district (a measured reserve of 6.6 million tons, an inferred reserve of 57.3 million tons, and a probable reserve of 48.6 million tons). Barnes (1967) reported 24 million tons of inferred reserves in the Chickaloon district. From a limited amount of drilling, May and Warfield (1957) computed a potential reserve of 14.6 million tons for the Little Susitna field.

\section{TEST WELLS}

Test-well (dry-hole) logs were examined to determine the distribution and thickness of coal beds. Selected well logs are shown on plate 2. S.W. Hackett, former DGGS geophysicist, assisted in interpreting the well logs and determined the stratigraphy.

The Tyonek-equivalent formation, as shown on plate 2, has $301 \mathrm{ft}$ of identified coal in 37 seams in the Lum Lovely Beaver Lakes 1 well. Electric logs indicate the possibility of 11 additional seams for a total of 48 seams and $347 \mathrm{ft}$ of coal. The Tyonek-equivalent formation in Atlantic Refinery Lorraine 1 has $202 \mathrm{ft}$ of coal in $1,250 \mathrm{ft}$. All well logs on plate 2 indicate several coal 
seams less than $3,000 \mathrm{ft}$ below the surface.

Unfortunately, the top $1,000 \mathrm{ft}$ of some oil wells is not logged. No attempt was made to quantify the subeconomic resources according to U.S. Geological Survey Bulletin 1450-B (1976).

\section{ACKNOWLEDGMENTS}

We thank G.R. Fakins and R.D. Merritt for their thoughtful review of the manuscript and K.S. Pearson for cartographic assistance.

\section{SELECTED BIBLIOGRAPHY}

Alaska Geological Society Stratigraphic Committee, 1969, Composite F-log columnar section for Kenai Group of Cook Inlet basin, Alaska: Anchorage, Alaska Geological Society, 1 pl. 1969, South to north stratigraphic correlation section, Anchor Point to Campbell Point, Cook Inlet basin, Alaska: Anchorage, Alaska Geological Society, $1 \mathrm{pl}$. 1969 , South to north stratigraphic correlation section, Kalgin Island to Beluga River, Cook Inlet basin, Alaska: Anchorage, Alaska Geological Society, 1 pl.

Apell, G.A., 1944, Moose Creek district of Matanuska coal fields, Alaska: U.S. Bureau of Mines Report of Investigations $3784,36 \mathrm{p}$.

Barnes, F.F., 1951, Mining and exploration in 1945 in the Wishbone Hill coal district, Matanuska Valley, Alaska: U.S. Geological Survey Bulletin 963-E, p. 127-213.

, 1962a, Geologic map of the lower Matanuska Valley, Alaska: U.S. Geological Survey Miscellaneous Geologic Inventory Map I-359, scale $1: 63,360$.

1962b, Topographic and geologic map of the Knob Creek area of the Wishbone Hill district, Matanuska Coal Field, Alaska: U.S. Geological Survey Coal Inventory Map C-51, scale $1: 6,000$.

, 1967, Coal resources of Alaska: U.S. Geological Survey Bulletin 1242-B, 35 p., 1 pl.

Barnes, F.F., and Ford, D.M., 1952, Coal prospects and coal exploration and development in the lower Matanuska Valley, Alaska, in 1950: U.S. Geological Survey Circular 154, 5 p.

Barnes, F.F., and Payne, T.G., 1956, The Wishbone Hill district, Matanuska Coal Field, Alaska: U.S. Geological Survey Bulletin 1016, 88 p.

Barnes, F.F., and Sokol, Daniel, 1959, Geology and coal resources of the Little Susitna district, Matanuska Coal Field, Alaska: U.S. Geological Survey Bulletin 1058-D, p. 121-138, pl. 7-11.

Calderwood, K.W., and Fackler, W.C., 1972, Proposed stratigraphic nomenclature for the Kenai Group, Cook Inlet basin, Alaska: American Association of Petroleum Geologists Bulletin, v. 56, no. 4, p. 739 754.
Capps, S.R., 1927, Geology of the upper Matanuska Valley, Alaska: U.S. Geological Survey Bulletin 791, 92 p., 16 pl.

1940, Geology of the Alaska railroad region: U.S. Geological Survey Bulletin 907 . 201 p., 9 pl.

Chapin, Theodore, 1920, Mining developments in the Matanuska Coal Field: U.S. Geological Survey Bulletin 712-D, p. 131-168, pl. 4-6. , 1921, Mining developments in the Matanuska Coal Field: U.S. Geological Survey Bulletin 714-D, p. 197-199.

Clardy, D.B., 1974 , Origin of the lower and middle Tertiary Wishbone and Tsadaka Formations, Matanuska Valley, Alaska: Fairbanks, University of Alaska unpublished M.S. thesis, $74 \mathrm{p}$.

Conwell, C.N., 1975, Coal - a review of the industry in the U.S. and Alaska with emphasis on mechanical cleaning: Fairbanks, University of Alaska unpub. lished M.S. thesis, p. 63-71.

Geer, M.R., and Fennessy, F.D., 1962, Washability of coals from the Matanuska Valley and Beluga River fields, Alaska: U.S. Bureau of Mines Report of Investigations $6017,33 \mathrm{p}$.

Geer, M.R., and Yancey, F.H., 1946, Washability characteristics and washing of coals from the Matanuska field of Alaska: U.S. Bureau of Mines Report of Investigations 3840,17 p., 7 fig.

Grantz, Arthur, 1961a, Geologic map and cross sections of the Anchorage D-2 Quadrangle and northeasternmost part of the Anchorage D-3 Quadrangle, Alaska: U.S. Geological Survey Miscellaneous Geologic Investigations Map I-342, scale 1:48,000. $1961 \mathrm{~b}$, Geologic map of the north two-thirds of the Anchorage D-1 Quadrangle, Alaska: U.S. Geological Survey Miscellaneous Investigations Map I-343, scale 1:48,000. , 1964, Stratigraphic reconnaissance of the Matanuska Formation in the Matanuska Valley, Alaska: U.S. Geological Survey Bulletin 1181-I, $33 \mathrm{p}$.

Hackett, S.W., 1977, Gravity survey of the Beluga basin and adjacent area, south-central Alaska: Alaska Division of Geological and Geophysical Surveys Geologic Report 49, 26 p., 3 pl.

Hartman, D.C., Pessel, G.H., and McGee, D.L., 1972, Kenai Group of Cook Inlet basin, Alaska: Alaska Division of Geological and Geophysical Surveys Open-file Report 49, 5 p., 11 pl.

Jolley, T.R., Toenges, A.L., and Turnbull, L.A., 1952, Bituminous-coal deposits in the vicinity of Eska, Matanuska Valley Coal Field, Alaska: U.S. Bureau of Mines Report of Investigations 4838, $82 \mathrm{p}$.

Kirschner, C.E., and Lyon, C.A., 1973, Stratigraphic and tectonic development of Cook Inlet petroleum province, in Arctic Geology - a symposium: American Association of Petroleum Geologists Memoir 19, p. 396-407.

Lyle, W.M., and Bragg, N.J., 1974, Coal bibliography for Alaska: Alaska Division of Geological and Geophysical Surveys Open-file Report 41, 31 p.

Magoon, L.B., Adkison, W.L., and Egbert, R.M., 1976, Map showing geology, wildcat wells, 'Tertiary plant 
fossil localities, $\mathrm{K}-\mathrm{Ar}$ age dates, and petroleum operations, Cook Inlet area, Alaska: U.S. Geological Survey Miscellaneous Geologic Inventory Map I-1019, 3 sheets.

Martin, G.C., 1906, A reconnaissance of the Matanuska Coal Field, Alaska: U.S. Geological Survey Bulletin 289,36 p., 5 pl. 1917, Geologic problems at the Matanuska coal mines: U.S. Geological Survey Bulletin 692-D, p. 269-282.

Martin, G.C., and Katz, F.J., 1912, Geology and coal fields of the lower Matanuska Valley, Alaska: U.S. Geological Survey Bulletin 500, 98 p., 19 pl.

May, R.R., and Warfield, R.S., 1957, Investigations of subbituminous-coal beds near Houston, westward extremity of Matanuska Coal Field, Alaska: U.S. Bureau of Mines Report of Investigations 5350, $20 \mathrm{p}$.

McGee, D.L., and O'Connor, K.M., 1975, Cook Inlet basin subsurface coal reserve study: Alaska Division of Geological and Geophysical Surveys Openfile Report 74, 19 p., 3 pl.

Paige, Sidney, and Knopl, Adolph, 1907, Geologic reconnaissance in the Matanuska and Talkeetna basins, Alaska: U.S. Geological Survey Bulletin $327,71 \mathrm{p}$.
Rao, P.D., 1975, Characterization of Alaskan coals: Focus on Alaska's coal, Fairbanks, University of Alaska, 1975, Proceedings: University of Alaska Mineral Industry Research Laboratory Report 37, p. 40.

Richards, R.W., and Waring, G.A., 1933, Progress of survey in the Anthracite Ridge district, Alaska: U.S. Geological Survey Bulletin 849-A, p. 5-17.

Tuck, Ralph, 1937, The Eska Creek coal deposits, Matanuska Valley, Alaska: U.S. Geological Survey Bulletin 880-D, p. 185-213.

U.S. Geological Survey, 1976, Coal resource classification system of the U.S. Bureau of Mines and U.S. Geological Survey: U.S. Geological Survey Bulletin 1450-B, p. B4-B7.

Warfield, R.S., 1962, Bituminous coal deposits of the Matanuska Coal Field, Alaska; central and western parts, Wishbone district: U.S. Bureau of Mines Report of Investigations $5950,190 \mathrm{p}$.

Waring, G.A., 1934, Core drilling for coal in the Moose Creek area, Alaska: U.S. Geological Survey Bulletin 857-E, p. 155-173, pl. 6-9. , 1936, Geology of the Anthracite Ridge coal district, Alaska: U.S. Geological Survey Bulletin 861,57 p., 14 pl. 